\title{
Gilpinia fennica (Forsius, 1911) new to Poland (Hymenoptera, Symphyta: Diprionidae), and a review of the species
}

\author{
Jerzy Borowski \& Dawid Marczak
}

Borowski, J. \& Marczak, D. 2015: Gilpinia fennica (Forsius, 1911) new to Poland (Hymenoptera, Symphyta: Diprionidae), and a review of the species. Entomol. Fennica 26: 177-180.

The paper presents information about the discovery of a new species of diprionid sawfly for the Polish forests. This is Finnish conifer sawfly Gilpinia fennica (Forsius). One female of the species was caught in a screen trap while trapping of saproxylic beetles in Kampinoski National Park. The Finnish conifer sawfly is the fifth species living on spruces in Poland. It is also one of the least observed European diprionid. Poland, after Finland, Russia, China and Sweden, is the $5^{\text {th }}$ country where this species has been discovered. In addition, the paper presents information on the geographical distribution and biology of the species.

J. Borowski, Department of Forest Protection and Ecology, Warsaw University of Life Sciences SGGW, ul. Nowoursynowska 159/34, 02-776 Warsaw, Poland; E-mail: jerzy_borowski@sggw.pl

D. Marczak, Kampinoski National Park, ul. Tetmajera 38, 05-080 Izabelin, Poland; University of Ecology and Management in Warsaw, ul. Olszewska 12, 00792 Warsaw, Poland; E-mail: dawid.marczak@gmail.com

Received 9 February 2015, accepted 29 June 2015

\section{Introduction}

The family Diprionidae (Hymenoptera, Symphyta) is not abundant in numbers of species, currently represented by 155 known species (Taeger et al. 2010), inhabiting exclusively coniferous trees and shrubs and is therefore most numerous in temperate climatic zone of the northern hemisphere. In Europe 23 species occur, 19 of them having been hitherto known from Poland (Huflejt 1997). Those living on pines (Pinus spp.) with a tendency to mass appearings are of some economical importance.

Despite rather good knowledge of pine-inhabiting diprionids, specific distinctness of some remains questionable (Viitasaari \& Varama
1987). In the recent catalogue of Polish animals (Skibińska \& Chudzicka 2004) 18 species have been listed (not including Gilpinia catocala Snellen van Vollenhoven).

Among Polish Diprionidae, four species, Gilpinia polytoma (Hartig), G. hercyniae (Hartig), G. abieticola (Dalla Torre) and Microdiprion fuscipennis (Forsius), have been considered to develop on spruces (Picea spp.). The former two are rather commonly found everywhere, while in Poland G. abieticola is known only from Beskidy Mts., and M. fuscipennis from the Białowieża Primaeval Forest (Huflejt 1997).

Below we present information about the fifth species of spruce-inhabiting diprionid found in Poland, Gilpinia fennica (Forsius). 


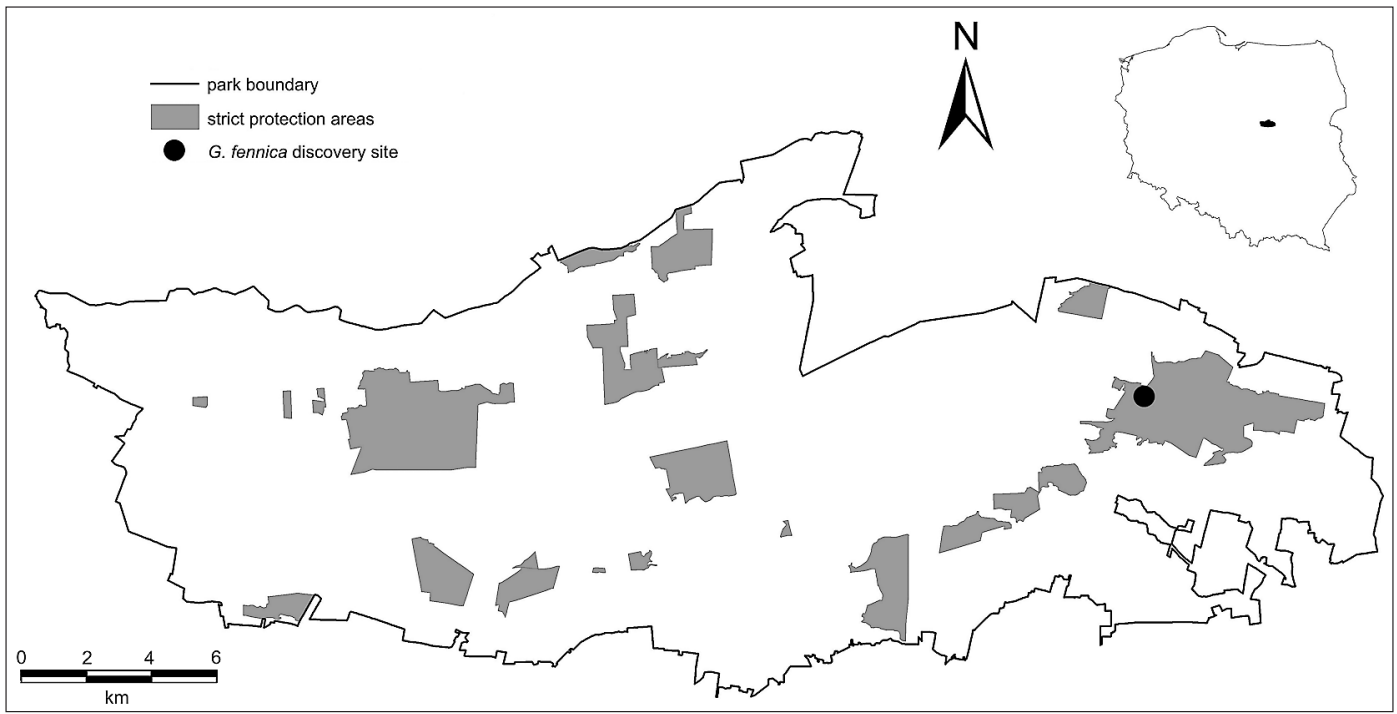

Fig. 1. Location of Kampinoski National Park and the place of discovery of Gilpinia fennica (Forsius) in Poland.

\section{Specifics of Polish finding of Gilpinia fennica}

Gilpinia fennica was accidentally collected in the course of studies on saproxylic beetles in Kampinos National Park (Fig. 1), having fallen into an IBL-2 type screen-trap in the strict protection area "Sieraków", div. 100b (Fig. 2). On the study site two such traps worked from the beginning of April to the end of July 2014, capturing, besides the "target" saproxylic beetles, many other groups of invertebrates. The content of the traps was emptied at the end of each month, categorized according to the systematic placement, and identified by ourselves or sent to appropriate specialists.

In April 2014 one female of G. fennica was captured in a screen-trap in Poland, div. 100b, UTM: DC89, IBL-2 type screen-trap, 1.-30.IV. 2014, D. Marczak leg., J. Borowski det. The

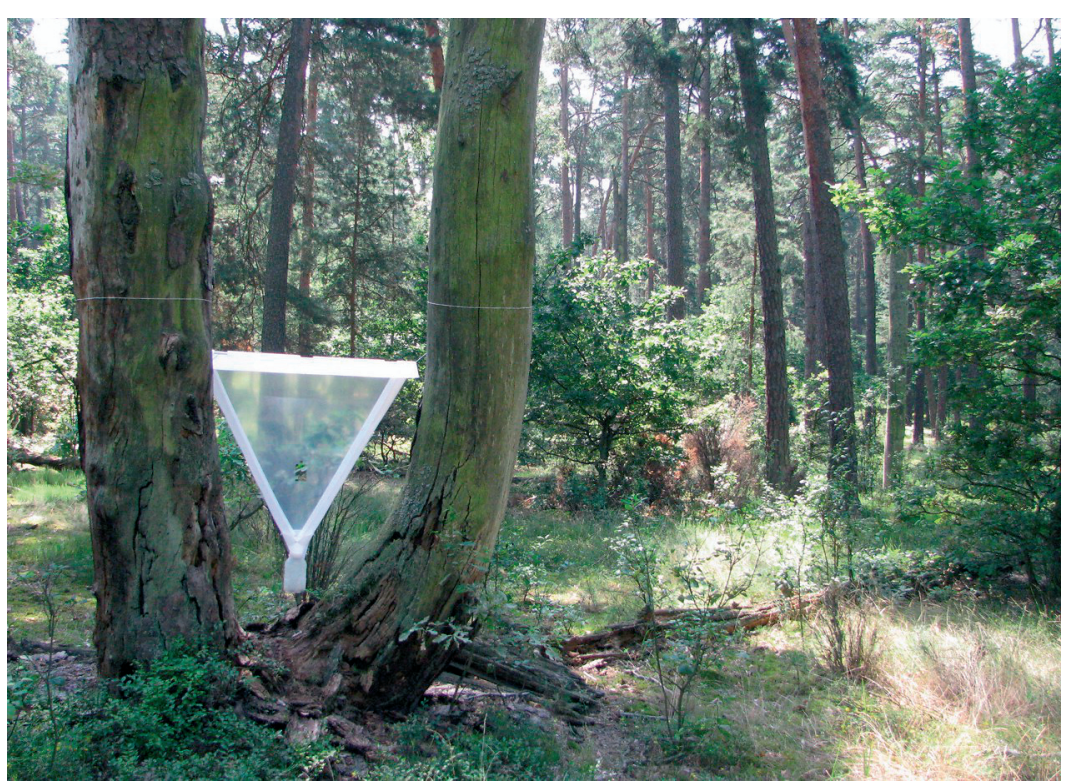

Fig. 2. An IBL-2 type screen trap used to catch insects in Kampinoski National Park. 
Fig. 3. Female of Gilpinia fennica (Forsius) collected in Kampinoski National Park, with a closer view of antenna in left bottom corner. Scale bar for the specimen: $5 \mathrm{~mm}$.

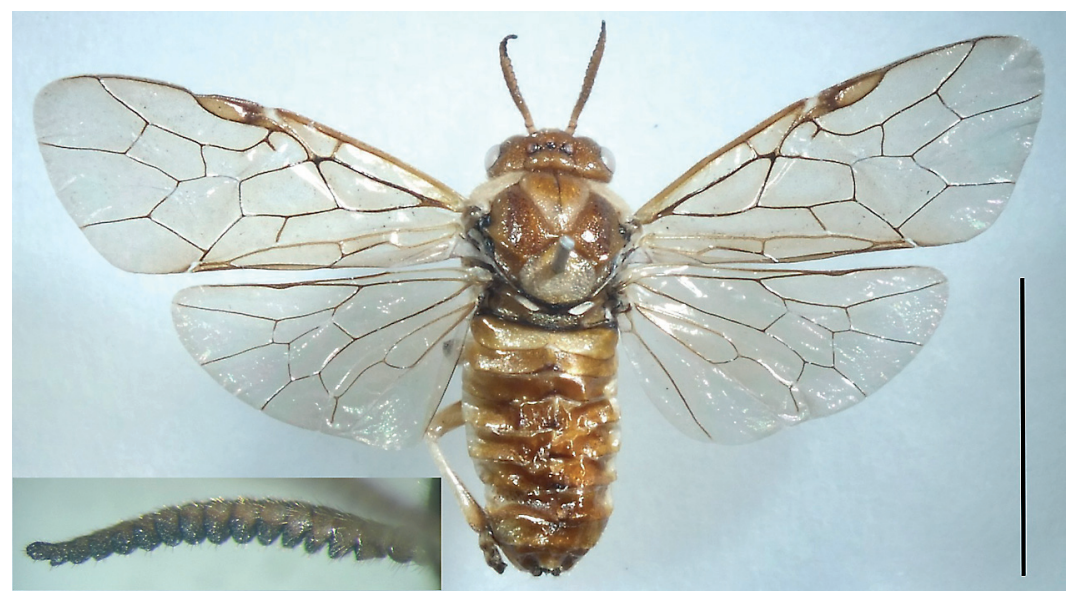

study area is covered by old (more than 196 years) pine forest with an admixture of oak and birch, undergrown by young oaks, pines, birches, and junipers; the nearest spruces grow some 380 $\mathrm{m}$ away from the trap where $G$. fennica was captured (div. 75d). These undergrowth spruces were 20 years old; the seedlings had been obtained from the nearby nursery in Julinek near Leszno.

The prepared specimen (Fig. 3) has been deposited in the collection of the Department of Forest Protection and Ecology, Warsaw University of Life Sciences SGGW in Rogów.

Together with $G$. fennica two species of pineinhabiting diprionids, Gilpinia frutetorum (Fabricius) and Diprion similis (Hartig), were trapped.

\section{Information about the species and discussion}

\subsection{Geographical distribution}

Gilpinia fennica is one of the rarest European diprionid sawfly. It was described from Finland (Forsius 1911) based on three females, and for nearly 70 years known only from that country (Enslin 1917, Gussakovskij 1947, Kontuniemi 1960, Beneš \& Křístek 1979). In 1979 it was found in Tannu-Oła Mts. (Siberia, near Mongolian border) (Ermolenko \& Zemkova 1979), and in the 1980's in the Dailing Distr. (Heilonggiang Prov., NE-China) (Xiao et al. 1985), Jakutia
(Viitasaari \& Varama 1987) and S-Sweden (Olofsson 1989). Thus, Poland is the fifth country from where the occurrence of this species has been ascertained.

Evidently, G. fennica should be considered representing the boreal euro-siberian element, and further studies may show its occurrence in north-eastern Europe and Siberia. The locality in the Kampinos National Park lies at some $850 \mathrm{~km}$ distance from the one where G. fennica has been found in Sweden and some $950 \mathrm{~km}$ from those in Finland. The area was formed during the last glaciation and some boreal species survived in depressions between dunes. Accordingly, the occurrence of $G$. fennica should be considered there a relict of the post-glacial times, when Polish spruce stands formed the continuous zone with boreal forests of northern Europe and Siberia.

\subsection{Bionomy}

Forsius (1911), besides the bare description, admitted to have known nothing about the bionomy of the species, and it was almost 50 years later that Kontuniemi (1960) quoted Dr. Thorwald Grönblom's information - later repeated by Beneš and Krístek (1979) - that the host-plant was spruce, Picea abies (L.) H. Karst. The first bionomical data were provided by Ermolenko and Zemkova (1979). In July 1966 Zemkova found 11 unknown larvae on a young (some $1.5 \mathrm{~m}$ high) undergrowth siberian spruce (Picea obovata Ledeb.) at some $200 \mathrm{~m}$ a.s.l. After having finished 
feeding and making cocoons on needles, in September one female emerged while the remaining eonymphs overwintered. It was 13 years later that these observations were published: the species in question had been determined as G. fennica. Kangas (1985) reports, according to his own studies in southern Finland, that oviposition takes place in June and July, and larvae feed together in large colonies. Finnish scientists (Viitasaari \& Varama 1987) report J. Kangas' unpublished observations that $G$. fennica places the eggs separately on lower part of a needle (at approximately basal 1/4), but according to Olofsson (1989) they may also be laid at midlength. The authors write that the species is rare and scarce, and that only in the years of generally more numerous occurrence of diprionids it may be found on sunny open places, e.g. in parks or on spruces used as hedges. The newest data were published by Olofsson (1989) who, from larvae collected in late June, had reared a female which then laid some 20 parthenogenetic eggs on neighbouring needles of a single spruce shoot. Only males emerged from these eggs, so in G. fennica, like in most other diprionids, arrhenotokous (hemozygioid) parthenogenesis has been documented.

Gilpinia fennica is the only European spruceinhabiting species whose larvae feed in groups throughout their life - in M. fuscipennis they also keep together after hatching but later instars spread to different sprouts and the last one is found always separately (Viitasaari \& Varama 1987). In our country all species of Gilpinia Benson have usually two generations a year, and the date of trapping of the female in April in the Kampinoski National Park suggests the same for G. fennica. This, however, needs confirmation by more intensive studies on the same or other (e.g. in north-eastern Poland) areas to elucidate the bionomy of the species under Polish conditions.

\section{Final remarks}

More than hundred years after the description, Gilpinia fennica remains a very rarely observed species, any finding may be considered an exceptional luck. Hopefully the intensification of studies allows to clarify its developmental preferences and to precise the bionomy and morpholo- gy of particular instars. No danger to Polish spruce forests from $G$. fennica is expectable. It should be considered an indicator species for those boreal spruce forests, or their remnants, which persisted uninterruptedly and, perhaps, the occurrence on these (probably not extensive) places of ecoclimatic niches resembling those of the boreal times.

\section{References}

Beneš, K. \& Kř́istek, J. 1979: Současný stav taxonomie evropských druhů čeledí Pamphiliidae, Diprionidae a Tenthredinidae (Hymenoptera, Symphyta) žijících na smrku. - Acta Universitatis Agriculturae, ser.C, (Facultas silviculturae) 48(1-4): 77-118. [In Czech.]

Enslin, E. 1917: Die Tenthredinoidea Mitteleuropas. VI. —Deutsche Entomologische Zeitschrift 1917(Beiheft 6): 539-662.

Ermolenko, V. M. \& Zemkova, R. I. 1979: O nakhodke Gilpinia fennica (Forsius) (Hymenoptera, Diprionidae) v Tuvinskoy ASSR. — Vestnik zoologii 1979(1): 70-71. [In Russian.]

Forsius, R. 1911: Über einige Diprion (Lophyrus Latr.) Arten. - Meddelanden af Societas pro Fauna et Flora Fennica 37(1910-1911): 178-183.

Gussakovskij, V. V. 1947: Insectes Hyménoptčres, Chalastogastra 2. - Fauna SSSR, Leningrad Academie des Sciences de l'URSS, Moscou. 234 pp.

Huflejt, T. 1997: 24. Hymenoptera-Błonkówki. Symphyta - Rośliniarki: 7-42. — In: Razowski, J. (ed.), Wykaz zwierząt Polski. Tom V. Wydawnictwa ISiEZ PAN, Kraków. 260 pp.

Kangas, J. K. 1985: Pälkäneen Sahapistiäisfauna 19531983. — Pälkäne-Seuran julkaisuja 5: 1-113.

Kontuniemi, T. 1960: Suomen sahapistiäistoukkien ravintokasvit. Die Futterpflanzen der Sägewespenlarven (Hymenoptera, Symphyta) Finnlands. - Animalia Fennica 9: 1-104.

Olofsson, E. 1989: Två för Sverige nya växtsteklar med kolonilevande larver på gran. - Entomologisk Tidskrift 110(1-2): 43-45.

Skibińska, E. \& Chudzicka, E. 2004: Borecznikowate Diprionidae: 276, 279-280. — In: Bogdanowicz, W., Chudzicka, E., Pilipiuk, I. \& Skibińska, E. (eds), Fauna Polski. Charakterystyka i wykaz gatunków. T.I. Muzeum i Instytut Zoologii PAN, Warszawa. 509 pp.

Taeger, A., Blank, S. M. \& Liston, A. D. 2010: World Catalog of Symphyta (Hymenoptera). - Zootaxa 2580: 1-1064.

Viitasaari, M. \& Varama, M. 1987: Sahapistiäiset 4. Havupistiäiset (Diprionidae). - Reports, University of Helsinki, Helsinki. 79 pp.

Xiao, G., Huang, X. \& Zhou, S. 1985: The Chinese sawflies of the family Diprionidae (Hymenoptera, Symphyta). - Scientia Silvae Sinicae 21(1): 30-43. 